\title{
Monitoring a half-century of change in a hardwood rangeland
}

\author{
KERRY L. HEISE AND ADINA M. MERENLENDER
}

Authors are Botanist and Staff Research Associate, Integrated Hardwood Range Management Program, Hopland Research and Extension Center, Hopland, Calif. 95449; and Cooperative Extension Specialist, Environmental Science, Policy, and Management, University of California, Berkeley, Calif. $94720-3110$.

\begin{abstract}
Changes in rangeland species composition can effect forage quality, ecosystem function, and biological diversity. Unfortunately, documenting species compositional change is difficult due to a lack of accurate historic records. We took advantage of herbarium records dating from the early 1950's to reconstruct the past flora of a 2,168 ha hardwood rangeland in Mendocino County, California , and then compared this to the current flora of the site. An inventory of vascular plants conducted from 1996 to 2001 added 44 native and 15 non-native species bringing the total number of species and infraspecific taxa at the study site to 671 . Of the original 612 species recorded prior to this study, 34 native and 1 non-native species could not be relocated. The percentage of non-native species increased from $19 \%$ in 1952 to $23 \%$ in 2001 . Based on estimates from the early 1950's, mid 1980's, and 1996 to 2001, at least 13 non-native species have increased in abundance, while some native species have decreased. Livestock grazing, competition with invasive species, conversions to different vegetation types, and transportation of propagules into the site by vehicles and livestock, combined with the difficulty of relocating rare species, are posed as the most likely causes for the documented changes.
\end{abstract}

Key Words: Northwest California, herbarium, oak woodlands, livestock, flora, invasive species

Hardwood rangelands in California cover an estimated 4.5 million ha and are characterized by an overstory canopy of hardwood trees, primarily in the genus Quercus. The overstory provides at least $10 \%$ cover; the understory is generally dominated by exotic annual grasses and forbs. Replacement of the native understory flora with a primarily non-native one occurred rapidly and on a very large scale over the past 200 years (Heady 1977, Mack 1989). The primary causes of this change are human induced such as livestock grazing, fire suppression, and facilitated dispersal (Rejmánek et al. 1991) resulting in an increased dominance by exotics and a subsequent loss of native species (Mooney and Drake 1987).

Change in understory species composition of oak woodlands, savanna, and grasslands represents a significant component of global environmental change including loss of biological diversi-

Authors wish to thank Chuck Vaughn, Bob Keiffer, and 2 anonymous reviewers for helpful comments on the manuscript.

Manuscript accepted 5 Oct. 01

\section{Resumen}

Cambios en la composición de especies del pastizal pueden afectar la calidad de forraje, la función del ecosistema y la diversidad biológica. Desafortunadamente, el documentar los cambios de la composición de especies es difícil debido a la falta de registros históricos certeros. Tomamos ventaja de los registros del herbario, que datan de inicio de la década de 1950, para reconstruir la flora pasada de 2,168 ha de un pastizal con árboles de madera dura en el condado de Mendocino, California, y la comparamos con la flora actual del sitio. Un inventario de las plantas vasculares conducido de 1996 al 2001 agregó 44 especies nativas y 25 especies no nativas totalizando 671el número de especies y taxas intraespecificas en el sitio de estudio. De las 612 especies originales registradas antes de este estudio, 34 nativas y una no nativa no pudieron ser relocalizadas. El porcentaje de especies no nativas se incrementó de $19 \%$ en 1952 a $23 \%$ en 2001. Basados en las estimaciones de inicios de la década de los 50 's, mediados de la década de los 80 's y de 1996 a 2001, al menos 13 especies no nativas han incrementado en abundancia, mientras algunas especies nativas han decrecido. El apacentamiento de ganado, la competencia con especie invasoras, la conversión a diferentes tipos vegetativos y el transporte de propágulos al sitio por vehículos y ganado, combinado con la dificultad de relocalizar especies raras son propuestas como las causas más probables de los cambios documentados.

ty, change in ecosystem function, and reduction in rangeland productivity (D'Antonio and Vitousek 1992, Campbell and Smith 2000). In particular, exotic annual grasses interfere significantly with native perennial grasses during all stages of growth (Hamilton et al. 1999), resulting in an increase in exotic annuals over time. Invading species can also differ functionally from the native species that they are replacing, resulting in a great overarching effect on ecosystems (Vitousek 1986).

Monitoring species compositional changes in California hardwood rangelands is essential for determining the sustainability of livestock grazing and necessary to address the lack of oak seedling survival. Because the understory of California's hardwood rangelands are dominated by exotic grasses and forbs, many lower in nutritional quality and palatability than native perennial species, the capacity of rangelands has been seriously decreased (Major 1955, Pettit et al. 1995). Annual grasses are adapted to heavy grazing and low nutrient availability (Jackson 1985), which has consequences for the way livestock grazing is practiced on site as well as the economic vitality of open range 
grazing operations. As range conditions deteriorate, livestock seek out less palatable plant species, increasing the use on these species, oak seedlings included. Additionally, the establishment of exotic annual grasses has been proposed as a limiting factor in the regeneration of some native oak species (Muick and Bartolome 1988, Gordon and Rice 1993).

Due to the scarcity of historic baseline information, few studies have examined long-term change on California rangelands. Using cover data from the 1930's, Holzman and Allen-Diaz (1991) documented 58 years of change in 21 blue oak (Quercus douglasii Hook. \& Arn.) woodland plots in California. Our study documents change over nearly a half-century by reconstructing the past flora of a hardwood rangeland in northwest California, comparing herbarium data to the modern flora. This was feasible due to the establishment of an extensive reference collection of vascular plants for the site in the early 1950's. A flora was later published (Murphy and Heady 1983) which included data on species abundance across the site from the early 1980's. This comprehensive set of scientific records, in combination with extensive documentation of landuse at the site, provided us with a means to identify newly established species and document changes in the relative abundance of some taxa.

\section{Study Site}

\section{Vegetation}

The study area encompasses the entire University of California Hopland Research and Extension Center, located in the interior north coast ranges of southeastern Mendocino County $\left(39^{\circ} 00^{\prime} \mathrm{N}\right.$, $\left.123^{\circ} 05^{\prime} \mathrm{W}\right)$. It encompasses nearly 2,168 hectares of moderately steep, predominately southwest-facing slopes in the Mayacmas Mountains, with elevations ranging from 183 to $914 \mathrm{~m}$. The natural vegetation reflects a mediterranean climate of hot dry summers and cool wet winters, with an average annual rainfall of $960 \mathrm{~mm}$. Oaks and other hardwoods are common overstory species of the lower elevation woodlands and include blue oak (Quercus douglasii Hook. \& Arn.), black oak ( $Q$. kelloggii Newb.), valley oak ( $Q$. lobata Nee), Oregon oak (Q. garryana Hook.), coast live oak ( $Q$. agrifolia $\mathrm{Nee})$, Shreve oak ( $Q$. parvula E. Greene var. shrevei (C.H. Muller) K. Nixon), California bay (Umbellularia californica (Hook. \& Arn.) Nutt.), Pacific madrone
(Arbutus menziesii Pursh), and California buckeye (Aesculus californicus (Spach) Nutt.). Grasslands and the understory of open oak woodland and savanna are dominated by non-native annual grasses such as slender wild oat (Avena barbata Link), big quaking grass (Briza maxima L.), hedgehog dogtail (Cynosurus echinatus L.), and barbed goatgrass (Aegilops triuncialis L.). Chaparral scrub consisting of chamise (Adenostoma fasciculatum Hook. \& Arn.), Arctostaphylos spp., Ceanothus spp., and Quercus spp., along with patches of closed cone pine (Pinus attenuata Lemmon) are common above $675 \mathrm{~m}$. Douglas fir (Pseudotsuga menziesii (Mirbel) Franco), California nutmeg (Torreya californica Torrey), and canyon live oak (Quercus chrysolepis Liebm.) form dense shaded canopies on steep north and east facing slopes. Numerous seasonal creeks, sag ponds, vernal pools and springs provide a diversity of wetland habitats and plant communities (Heise and Merenlender 1999).

\section{Historic Data}

The Center was established as a range experiment station in 1951. The following year, a botanical survey was initiated to document all species of vascular plants on the property. By 1954 nearly 450 species were recorded. During the next 30 years of sporadic collecting only 137 species were added to the flora, bringing the total to almost 600 . At this time a list of the vascular plants for the Center was published (Murphy and Heady 1983). Only a few more species were added to the flora through the 1980's and mid 1990's, bringing the total number of vascular species and infraspecific taxa to 612. Alfred $H$. Murphy, the Center's first superintendent, and Harold F. Heady, U.C. Berkeley Professor of Range Management, initiated the inventory, and alone contributed 1,177 specimens to the Center's herbarium, about $92 \%$ of the collection.

\section{Livestock and Forage Management}

Prior to the University's purchase of the property the area was used as a sheep range. Since then, between 1,500 and 2,000 sheep continue to use approximately $2 / 3$ of the Center. Much of the livestock grazing pressure across this range is light because of the terrain and dense wooded vegetation; the heaviest use occurs on approximately 300 ha and is concentrated in lambing and winter feeding pastures or seeded grassland near the headquarters area. Livestock are excluded from approximately 435 ha in designated "biological areas", research pastures, and steep, wooded terrain outside of fenced pasture boundaries. Rangeland improvement practices during the 1960's and 1970's, aimed at increasing agricultural production, resulted in the conversion of approximately 300 ha of oak woodland and chamise chaparral to exotic grassland (Murphy 1976, 1978). In addition, university staff and researchers intentionally introduced at least 19 exotic plant species. These were seeded into pastures following fire or other forms of clearing to improve range forage, and since have expanded their ranges well beyond the initial introduction sites. Some of the common species include smilo grass (Piptatherum miliaceum (L.) Cosson), harding grass (Phalaris aquatica L.), orchard grass (Dactylis glomerata L.), rose clover (Trifolium hirtum All.) and subterranean clover ( $T$. subterraneum L.).

\section{Methods}

Between 1996 and 2001 we conducted an extensive inventory of vascular plants across the entire Center. First, the information from over 1,275 specimen labels from the Center's herbarium was updated to reflect mis-identifications, recent scientific name changes, and reductions due to synonymy (Hickman 1993), and then incorporated into a database. From this, species lists with location, habitat, and collection date were produced to facilitate the relocation of previously recorded taxa. Most of the herbarium specimens (75\%) contained general location descriptions such as pasture name only, while the remaining $25 \%$ had more specific site locations. Because of the intensity and thoroughness during the first 3 years of the original botanical survey in the early 1950's, we assume that taxa not collected then were probably sparse, inaccessible, or absent. An extensive road system over 72 $\mathrm{km}$ in length facilitated access throughout the Center's property; roadless areas were surveyed on foot. Voucher specimens for previously unrecorded taxa were collected and deposited into the Center's herbarium.

Relative terms describing abundance at the collection site ("Sparse", "Occasional", "Numerous") were assigned to 479 specimens (313 species) that were collected between 1952 and 1954. This site-specific information provided a rough estimate of species abundance across the Center in cases where there were similar abundance estimates for multiple collections of the same species. In the early 1980's Murphy and Heady (1983) estimated the abundance of 600 
vascular plant species across the entire Center using similar non-absolute terms, which we adopted during our field work to provide consistency. Thus, for about half of the flora we were able to obtain comparable abundance estimates from the early 1950 's, early 1980's, and 1996 to 2001 , and for the entire flora between the early 1980 's, and 1996 to 2001. Given the subjectivity of these terms, we only present taxa that have undergone extreme declines or increases, thus representing notable change.

\section{Results}

\section{New Taxa}

The 1996 to 2001 inventory added 59 species (44 native and 15 non-native) in 29 families to the flora, bringing the total number of species and infra-specific taxa at the field station to 671 (Table 1). More than half (34) of the new additions were native dicots, followed by non-native dicots (14), native monocots (8), nonnative monocots (1), and fern and fern allies (2). Asteraceae was the most represented family with 7 native and 4 nonnative species, followed by Apiaceae, Cyperaceae, and Scrophulariaceae (Table $2)$. Of the 44 native species, 22 were found in areas where sheep have been excluded, such as the "Biological Areas", rock outcrops, or other areas inaccessible to livestock, 12 in areas lightly grazed, 6 in moderate, and 4 in sites with heavy grazing pressure. Of the 15 new nonnative species, 3 were found in ungrazed areas, 3 in lightly grazed, 2 in moderately grazed, 6 in heavy grazed areas, and 1 found throughout all grazing regimes. Almost half of all new species found occurred in wetland habitats such as vernal pools, sag ponds, springs, and seasonal creeks.

\section{Missing Taxa}

Species loss was chiefly confined to plants of low abundance and occurred across a wide variety of habitat types and grazing regimes. Of the original 612 species that were documented at the Center prior to this study, 34 native and 1 non-native species could not be relocated (Table 3). Over half of the missing species (21) were native dicots, followed by native monocots (13), and non-native dicots (1). Although 19 families were represented, Poaceae, Asteraceae, and Cyperaceae accounted for roughly half of the species lost. Thirteen of the missing species occurred on sites that receive heavy graz-
Table 1. Floristic summary data for the University of California Hopland Research and Extension Center, Calif.

\begin{tabular}{lcccc}
\hline \hline & & \multicolumn{2}{c}{ Native } & \multicolumn{2}{c}{ Non-Native } \\
Taxa & Families & Genera & Taxa & Taxa \\
\hline Ferns and Fern Allies & 10 & 16 & 18 & 1 \\
Gymnosperms & 3 & 5 & 4 & 102 \\
Dicots & 71 & 258 & 374 & 52 \\
Monocots & 11 & 75 & 120 & 155 \\
Total & 95 & 354 & 516 & \\
\hline
\end{tabular}

ing pressure, 3 on moderately grazed, 9 on lightly grazed, and 10 in areas with no grazing. A majority of the 35 species lost occurred in grassland, chaparral, or wetland habitats.

\section{Changes in Species Abundance}

Many non-native species presumed absent or sparse during the early 1950's have since undergone dramatic increases in abundance (Table 4). For example,
Table 2. New species found at the University of California Hopland Research and Extension Center, California during 1996-2001 inventory period. Habitat: $\mathbf{C}=$ chaparral, $\mathbf{G}=$ grassland, $\mathbf{H}=$ hardwood forest, $\mathbf{X}=$ xeric woodland, $\mathbf{O}=$ outcrop/crevice, $\mathbf{W}=$ wetland, $\mathbf{R}=$ roadcut. Grazing: $\mathbf{N}=$ none, $\mathrm{L}=$ light, $\mathrm{M}=$ moderate, $\mathrm{H}=$ heavy

\begin{tabular}{|c|c|c|c|}
\hline Species & Habitat & Grazing & Native \\
\hline $\begin{array}{l}\text { Dryopteridaceae } \\
\text { Athyrium alpestre var. americanum }\end{array}$ & $\mathrm{O}$ & $\mathrm{N}$ & $\mathrm{Y}$ \\
\hline $\begin{array}{l}\text { Selaginellaceae } \\
\text { Selaginella wallacei }\end{array}$ & $\mathrm{O}$ & $\mathrm{N}$ & $\mathrm{Y}$ \\
\hline $\begin{array}{l}\text { Apiaceae } \\
\text { Lomatium dissectum } \\
\text { Lomatium vaginatum } \\
\text { Oenanthe sarmentosa } \\
\text { Tauschia kelloggii } \\
\text { Torilis arvensis }\end{array}$ & $\begin{array}{c}\mathrm{O} \\
\mathrm{H} \\
\mathrm{W} \\
\mathrm{H} \\
\mathrm{X}, \mathrm{G}\end{array}$ & $\begin{array}{c}\mathrm{N} \\
\mathrm{N} \\
\mathrm{N} \\
\mathrm{L} \\
\mathrm{N}, \mathrm{L}, \mathrm{M}\end{array}$ & $\begin{array}{l}\mathrm{Y} \\
\mathrm{Y} \\
\mathrm{Y} \\
\mathrm{Y} \\
\mathrm{N}\end{array}$ \\
\hline $\begin{array}{l}\text { Asteraceae } \\
\text { Euthamia occidentalis } \\
\text { Gnaphalium luteo-album } \\
\text { Hesperevax acaulis var. ambusticola } \\
\text { Hesperevax sparsiflora } \\
\text { Layia septentrionalis } \\
\text { Solidago californica } \\
\text { Soliva sessilis } \\
\text { Stephanomeria elata } \\
\text { Tolpis barbata } \\
\text { Tracyina rostrata } \\
\text { Tragopogon porrifolius }\end{array}$ & $\begin{array}{c}\text { W } \\
\text { W } \\
\text { C } \\
\text { G } \\
\text { X } \\
\text { W } \\
\text { R } \\
\text { W } \\
\text { X } \\
\text { G } \\
\text { G }\end{array}$ & $\begin{array}{l}\mathrm{M} \\
\mathrm{H} \\
\mathrm{L} \\
\mathrm{L} \\
\mathrm{L} \\
\mathrm{L} \\
\mathrm{H} \\
\mathrm{L} \\
\mathrm{L} \\
\mathrm{H} \\
\mathrm{L}\end{array}$ & $\begin{array}{l}\mathrm{Y} \\
\mathrm{N} \\
\mathrm{Y} \\
\mathrm{Y} \\
\mathrm{Y} \\
\mathrm{Y} \\
\mathrm{N} \\
\mathrm{Y} \\
\mathrm{N} \\
\mathrm{Y} \\
\mathrm{N}\end{array}$ \\
\hline $\begin{array}{l}\text { Boraginaceae } \\
\text { Myosotis discolor }\end{array}$ & W & $\mathrm{N}$ & $\mathrm{Y}$ \\
\hline $\begin{array}{l}\text { Brassicaceae } \\
\text { Carderia draba } \\
\text { Erysimum capitatum }\end{array}$ & $\begin{array}{l}\mathrm{W} \\
\mathrm{O}\end{array}$ & $\begin{array}{l}\mathrm{N} \\
\mathrm{N}\end{array}$ & $\begin{array}{l}\mathrm{N} \\
\mathrm{Y}\end{array}$ \\
\hline $\begin{array}{l}\text { Campanulaceae } \\
\text { Heterocodon rariflorum }\end{array}$ & W & $\mathrm{L}$ & $\mathrm{Y}$ \\
\hline $\begin{array}{l}\text { Caprifoliaceae } \\
\text { Symphoricarpos mollis } \\
\text { Caryophyllaceae }\end{array}$ & $\mathrm{H}$ & $\mathrm{L}$ & $\mathrm{Y}$ \\
\hline $\begin{array}{l}\text { Sagina apetala } \\
\text { Scleranthus annuus ssp. annuus }\end{array}$ & $\begin{array}{l}\text { W } \\
\text { G }\end{array}$ & $\begin{array}{l}\mathrm{M} \\
\mathrm{L}\end{array}$ & $\begin{array}{l}\mathrm{Y} \\
\mathrm{N}\end{array}$ \\
\hline $\begin{array}{l}\text { Crassulaceae } \\
\text { Sedum obtusatum ssp. retusum }\end{array}$ & $\mathrm{O}$ & $\mathrm{N}$ & $\mathrm{Y}$ \\
\hline $\begin{array}{l}\text { Ericaceae } \\
\text { Arctostaphylos canescens ssp. sonomensis } \\
\text { Chimaphila menziesii }\end{array}$ & $\begin{array}{l}\mathrm{C} \\
\mathrm{H}\end{array}$ & $\begin{array}{l}\mathrm{L} \\
\mathrm{N}\end{array}$ & $\begin{array}{l}\mathrm{Y} \\
\mathrm{Y}\end{array}$ \\
\hline $\begin{array}{l}\text { Euphorbiaceae } \\
\text { Euphorbia spathulata }\end{array}$ & $X$ & $\mathrm{~L}$ & $\mathrm{Y}$ \\
\hline
\end{tabular}

(Table 2 continued on page 415) 
(Table 2 Continued).

\begin{tabular}{|c|c|c|c|}
\hline Species & Habitat & Grazing & Native \\
\hline \multicolumn{4}{|l|}{ Fabaceae } \\
\hline Lotus pinnatus & $\mathrm{W}$ & $\mathrm{N}$ & $\mathrm{Y}$ \\
\hline Trifolium gracilentum var. gracilentum & G & M & $\mathrm{Y}$ \\
\hline Vicia hirsuta & W & $\mathrm{N}$ & $\mathrm{N}$ \\
\hline \multicolumn{4}{|l|}{ Gentianaceae } \\
\hline Cicendia quadrangularis & $\mathrm{W}$ & $\mathrm{H}$ & $\mathrm{Y}$ \\
\hline \multicolumn{4}{|l|}{ Lamiaceae } \\
\hline Satureja douglasii & $\mathrm{H}$ & $\mathrm{N}$ & $\mathrm{Y}$ \\
\hline Lamium purpureum & $\mathrm{R}$ & $\mathrm{H}$ & $\mathrm{N}$ \\
\hline \multicolumn{4}{|l|}{ Linaceae } \\
\hline Linum bienne & W & $\mathrm{H}$ & $\mathrm{N}$ \\
\hline \multicolumn{4}{|l|}{ Onagraceae } \\
\hline Clarkia concinna ssp. concinna & $\mathrm{H}$ & $\mathrm{N}$ & $\mathrm{Y}$ \\
\hline Epilobium brachycarpum & W & $\mathrm{H}$ & $\mathrm{Y}$ \\
\hline \multicolumn{4}{|l|}{ Polemoniaceae } \\
\hline Gilia sinistra ssp. pinnatisecta & $\mathrm{C}$ & $\mathrm{N}$ & $\mathrm{Y}$ \\
\hline \multicolumn{4}{|l|}{ Polygonaceae } \\
\hline Rumex conglomeratus & W & M & $\mathrm{N}$ \\
\hline \multicolumn{4}{|l|}{ Portulacaceae } \\
\hline Claytonia exigua & $\mathrm{O}$ & $\mathrm{N}$ & $\mathrm{Y}$ \\
\hline \multicolumn{4}{|l|}{ Portulacaceae } \\
\hline Claytonia exigua & $\mathrm{O}$ & $\mathrm{N}$ & $\mathrm{Y}$ \\
\hline \multicolumn{4}{|l|}{ Rubiaceae } \\
\hline Sherardia arvensis & W & $\mathrm{N}$ & $\mathrm{N}$ \\
\hline \multicolumn{4}{|l|}{ Scrophulariaceae } \\
\hline Collinsia parviflora & $\mathrm{X}$ & M & $\mathrm{Y}$ \\
\hline Cordylanthus pilosus & $\mathrm{X}$ & $\mathrm{N}$ & $\mathrm{Y}$ \\
\hline Parentucellia viscosa & $\mathrm{W}, \mathrm{R}$ & $\mathrm{H}$ & $\mathrm{N}$ \\
\hline Veronica anagallis-aquatica & W & $\mathrm{H}$ & $\mathrm{N}$ \\
\hline \multicolumn{4}{|l|}{ Solanaceae } \\
\hline Solanum americanum & W & $\mathrm{N}$ & $\mathrm{Y}$ \\
\hline \multicolumn{4}{|l|}{ Valerianaceae } \\
\hline \multicolumn{4}{|l|}{ Verbenaceae } \\
\hline Phyla nodiflora & G & $\mathrm{H}$ & $\mathrm{Y}$ \\
\hline Verbena lasiostachys & W & $\mathrm{N}$ & $\mathrm{Y}$ \\
\hline \multicolumn{4}{|l|}{ Cyperaceae } \\
\hline Carex barbarae & W & $\mathrm{N}$ & $\mathrm{Y}$ \\
\hline Carex comosa & W & $\mathrm{N}$ & $\mathrm{Y}$ \\
\hline Carex globosa & $\mathrm{H}$ & $\mathrm{N}$ & $\mathrm{Y}$ \\
\hline Carex subfusca & W & M & $\mathrm{Y}$ \\
\hline Scirpus californicus & $\mathrm{W}$ & $\mathrm{N}$ & $\mathrm{Y}$ \\
\hline \multicolumn{4}{|l|}{ Orchidaceae } \\
\hline Corallorhiza maculata & $\mathrm{H}$ & $\mathrm{N}$ & $\mathrm{Y}$ \\
\hline \multicolumn{4}{|l|}{ Poaceae } \\
\hline Festuca arundinacea & $\mathrm{G}$ & $\mathrm{L}$ & $\mathrm{N}$ \\
\hline Melica hardfordii & $\mathrm{H}$ & $\mathrm{L}$ & $\mathrm{Y}$ \\
\hline \multicolumn{4}{|l|}{ Typhaceae } \\
\hline Sparganium eurycarpum ssp. eurycarpum & W & $\mathrm{N}$ & $\mathrm{Y}$ \\
\hline
\end{tabular}

pennyroyal (Mentha pulegium L.), an herbaceous perennial first collected on the Center in 1969, now dominates the margins of several permanent ponds and seeps in grazed and ungrazed sites alike. Barbed goatgrass (Aegilops triuncialis L.), another extremely invasive plant, was first collected here in 1961 and is now the dominant species on approximately 125 ha of serpentine grassland. The currently widespread and abundant Japanese Hedge-Parsley (Torilis arvensis (Hudson) Link.) was first collected in 1996, which suggests a rapid increase in abundance over the past 10 years. Noted as "sparse" and "occasional" respectively in 1983, big quakinggrass (Briza maxima L.) and hedgehog dogtail (Cynosurus echinatus L.) now comprise the dominant understory of oak woodlands on several south and southwest-facing slopes.
While many introduced species have become established and have increased in abundance at the Center, some native herbaceous perennials, such as rancher's fireweed (Amsinckii menziesii (Lehm.) Nelson \& J.F. Macbr.), owl's clover (Castilleja densiflora (Benth.) Chuang \& Heckard), Rigiopappus leptocladus A. Gray, and modesty (Whipplea modesta Torrey), which were considered numerous in the early fifties, are now sparse in occurrence. Other species that were common in occurrence in the fifties and now missing include Brewer's milkvetch (Astragalus breweri A. Grey), varied-leaf Collomia (Collomia heterophylla Hook.), and tufted hairgrass (Deschampsia cespitosa (L.) Beauv. var. cespitosa). Because of the subjective nature of the abundance measures, smaller changes for other species have undoubtedly occurred but cannot be presented with confidence.

\section{Discussion}

The initial plant survey at the Center in the early 1950's attempted to catalog all the known vascular plants, establishing valuable baseline floristic information for a 2,168 ha rangeland. Our study represents the first step in documenting the floristic changes that have occurred since the early 1950 's. As a result of our inventory we observed the following trends: 1) the occurrence of new native taxa previously undetected, 2) new non-native species have been established at the site, 3) some already established non-native species have greatly increased in abundance, 4) some missing taxa are clearly extirpated from the site, and 5) the missing taxa include some species that may be too rare to relocate over the course of the study. As expected, we added more non-native species to the Center's flora, whereas the addition of native species gave us confidence in the thoroughness of our survey methods. From records at the Center there is evidence that some rangeland management practices led to species loss and the spread of exotic plants. Access to management records that can help explain possible causes of change is an advantage of doing this type of study on a public research facility.

We documented an increase in nonnative species richness which is characteristic of the spread of invasive species in western lowland California (Randall et al. 1998). Non-natives at the Center are being added to the flora at a rate of 1.3 species per year, while several of those already 
Table 3. Plants that could not be relocated at the University of California Hopland Research and Extension Center, California following a 1996-2001 inventory. Habitat: $R=$ roadcut, $C=$ chaparral, $\mathbf{G}=$ grassland, $\mathbf{H}=$ hardwood forest, $\mathbf{W}=$ wetland, $\mathbf{X}=$ xeric woodland. Grazing: $\mathbf{N}=$ none, $\mathrm{L}=$ light, $\mathrm{M}=$ moderate, $\mathrm{H}=$ heavy

\begin{tabular}{|c|c|c|c|}
\hline Species & Habitat & Grazing & Native \\
\hline $\begin{array}{l}\text { Apiaceae } \\
\text { Perideridia gairdneri }\end{array}$ & G & $\mathrm{N}$ & $\mathrm{Y}$ \\
\hline $\begin{array}{l}\text { Asteraceae } \\
\text { Aster radulinus } \\
\text { Cirsium remotifolium } \\
\text { Lessingia nemaclada } \\
\text { Microseris laciniata ssp. laciniata }\end{array}$ & $\begin{array}{c}\mathrm{H} \\
\mathrm{G} \\
\mathrm{GL} \\
\mathrm{G}\end{array}$ & $\begin{array}{l}\mathrm{H} \\
\mathrm{N} \\
\mathrm{Y} \\
\mathrm{H}\end{array}$ & $\begin{array}{l}\mathrm{Y} \\
\mathrm{Y}\end{array}$ \\
\hline $\begin{array}{l}\text { Boraginaceae } \\
\text { Plagiobothrys stipitatus var. micranthus }\end{array}$ & W & $\mathrm{H}$ & Y \\
\hline $\begin{array}{l}\text { Brassicaceae } \\
\text { Tropidocarpum gracile }\end{array}$ & G L, & $\mathrm{H}$ & $\mathrm{Y}$ \\
\hline $\begin{array}{l}\text { Cistaceae } \\
\text { Helianthemum suffrutescens }\end{array}$ & $\mathrm{C}$ & $\mathrm{L}$ & Y \\
\hline $\begin{array}{l}\text { Crassulaceae } \\
\text { Sedum radiatum }\end{array}$ & $\mathrm{C}$ & $\mathrm{N}$ & Y \\
\hline $\begin{array}{l}\text { Fabaceae } \\
\text { Astragalus breweri } \\
\text { Gentianaceae }\end{array}$ & G & $\mathrm{H}$ & Y \\
\hline Centaurium davyi & $W$ & $\mathrm{~N}$ & $\mathrm{Y}$ \\
\hline $\begin{array}{l}\text { Loasaceae } \\
\text { Mentzelia laevicaulis } \\
\text { Mentzelia micrantha }\end{array}$ & $\begin{array}{l}\mathrm{R} \\
\mathrm{R}\end{array}$ & $\begin{array}{l}\mathrm{L} \\
\mathrm{L}\end{array}$ & $\begin{array}{l}\mathrm{Y} \\
\mathrm{Y}\end{array}$ \\
\hline $\begin{array}{l}\text { Malvaceae } \\
\text { Abutilon theophrasti }\end{array}$ & $\mathrm{W}$ & $\mathrm{N}$ & $\mathrm{N}$ \\
\hline $\begin{array}{l}\text { Onagraceae } \\
\text { Camissonia californica } \\
\text { Clarkia unguiculata }\end{array}$ & $\begin{array}{l}\mathrm{W} \\
\mathrm{R}\end{array}$ & $\begin{array}{l}\mathrm{L} \\
\mathrm{L}\end{array}$ & $\begin{array}{l}\mathrm{Y} \\
\mathrm{Y}\end{array}$ \\
\hline $\begin{array}{l}\text { Orobanchaceae } \\
\text { Orobanche uniflora }\end{array}$ & $\mathrm{G}$ & $\mathrm{H}$ & $\mathrm{Y}$ \\
\hline $\begin{array}{l}\text { Papaveraceae } \\
\text { Dendromecon rigida }\end{array}$ & $\mathrm{CN}$ & Y & \\
\hline $\begin{array}{l}\text { Polemoniaceae } \\
\text { Collomia diversifolia } \\
\text { Collomia heterophylla }\end{array}$ & $\begin{array}{l}\mathrm{H} \\
\mathrm{X}\end{array}$ & $\begin{array}{l}\mathrm{H} \\
\mathrm{N}\end{array}$ & $\begin{array}{l}\mathrm{Y} \\
\mathrm{Y}\end{array}$ \\
\hline $\begin{array}{l}\text { Polygonaceae } \\
\text { Chorizanthe polygonoides }\end{array}$ & $\mathrm{C}$ & $\mathrm{N}$ & $\mathrm{Y}$ \\
\hline $\begin{array}{l}\text { Ranunculaceae } \\
\text { Aquilegia eximia }\end{array}$ & $\mathrm{C}$ & $\mathrm{N}$ & $\mathrm{Y}$ \\
\hline $\begin{array}{l}\text { Cyperaceae } \\
\text { Cyperus erythrorhizos } \\
\text { Cyperus squarrosus } \\
\text { Eleocharis radicans }\end{array}$ & $\begin{array}{l}\text { W N, } \\
\text { W } \\
\text { W }\end{array}$ & $\begin{array}{l}\mathrm{M} \\
\mathrm{M} \\
\mathrm{M}\end{array}$ & $\begin{array}{l}\mathrm{Y} \\
\mathrm{Y} \\
\mathrm{Y}\end{array}$ \\
\hline $\begin{array}{l}\text { Liliaceae } \\
\text { Fritillaria recurva } \\
\text { Lilium rubescens }\end{array}$ & $\begin{array}{l}\mathrm{C} \\
\mathrm{C}\end{array}$ & $\begin{array}{l}\mathrm{L} \\
\mathrm{N}\end{array}$ & $\begin{array}{l}\mathrm{Y} \\
\mathrm{Y}\end{array}$ \\
\hline $\begin{array}{l}\text { Poaceae } \\
\text { Agrostis hallii } \\
\text { Calamagrostis koelerioides } \\
\text { Calamagrostis purpurascens } \\
\text { Calamagrostis rubescens } \\
\text { Deschampsia cespitosa } \\
\text { Festuca viridula } \\
\text { Leersia oryzoides } \\
\text { Pleuropogon californicus }\end{array}$ & $\begin{array}{c}\mathrm{X} \\
\mathrm{C} \\
\mathrm{C} \mathrm{H} \text {, } \\
\mathrm{H} \\
\mathrm{W} \\
\mathrm{C} \\
\mathrm{W} \\
\mathrm{W}\end{array}$ & $\begin{array}{l}\mathrm{H} \\
\mathrm{L} \\
\mathrm{L} \\
\mathrm{H} \\
\mathrm{H} \\
\mathrm{L} \\
\mathrm{H} \\
\mathrm{H}\end{array}$ & $\begin{array}{l}\mathrm{Y} \\
\mathrm{Y} \\
\mathrm{Y} \\
\mathrm{Y} \\
\mathrm{Y} \\
\mathrm{Y} \\
\mathrm{Y} \\
\mathrm{Y}\end{array}$ \\
\hline
\end{tabular}

established have undergone dramatic local range extensions. Most of the new introduced species were found in areas accessed by livestock or adjacent to roads where they could have been carried in by areas, and are conspicuously absent in dense chaparral, shaded hardwood forest, and on steep rocky outcrops. Roughly one third of the Center's 155 non-native species are annual grasses, followed by annual forbs primarily in Asteraceae and Fabaceae. Today, non-native plant species on the Center comprise $23 \%$ of the total flora compared to $19 \%$ in the early 1950 's,

By the time the University of California acquired the property in 1951, the nonnative flora was already well established. Herbarium records indicate that by 1954 over 90 introduced species occurred on the Center; of these, 22 were considered numerous at their collection sites. Thirty years later there were 136 introduced species, and by 2001 the number had grown to 155 (Fig. 1). This represents a $71 \%$ increase in non-native species over a period of 45 years. In contrast, the entire state of California saw a $31 \%$ increase in non-native plant species for a similar period between 1959 and 1998 (Randall et al. 1998).

Many of the new native species found during our inventory were likely overlooked during earlier surveys because of their rarity or locations that were difficult to access. For example, spikemoss (Selaginella wallacei Hieron.) was common on several north-facing boulders camouflaged with mosses and ferns, and an individual wallflower (Erysimum capitatum (Douglas) E. Greene) was located within a crevice high on a steep cliff face. Many others were found on steep wooded slopes outside of fenced pastures. Four plants considered rare in California were also found (Skinner and Pavlik 1994). The Bristly sedge (Carex comosa Boott) is considered rare across its entire range in several western states in the U.S., beaked Tracyina (Tracyina rostrata S.F. Blake) is known from fewer than a dozen populations in northwest California, Sonoma manzanita (Arctostaphylos canescens Eastw. ssp. sonomensis (Eastw.) P. Wells) occurs on chaparral sites in Northwest California, and Colusa Layia (Layia septentrionalis Keck) is a serpentine endemic of California's Interior Coast Ranges. Documenting these locations adds to an important body of information for conservation biologists and resource protection agencies monitoring rare species occurrences.

Over half of the missing taxa were originally recorded as "rare" or "sparse" and may have been overlooked during our inventory. These species were originally collected in upland areas with little or no grazing. Furthermore, there was nothing about the species composition at the origi- 


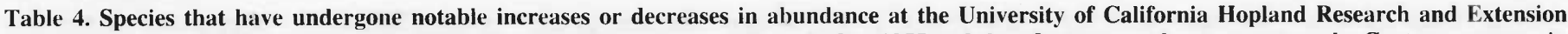

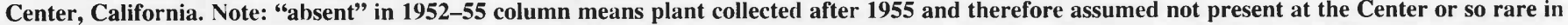
occurrence it was missed during first years of inventory.

\begin{tabular}{|c|c|c|c|c|}
\hline Species & Exotic & $1952-55$ & 1983 & $1996-01$ \\
\hline Amsinckii menziesii (Fiddleneck) & & numerous & occasional & sparse \\
\hline Castilleja densiflora (Owl's Clover) & & numerous & occasional & sparse \\
\hline Rigiopappus leptocladus & & numerous & numerous & sparse \\
\hline Whipplea modesta (Yerba de Selva) & & numerous & occasional & sparse \\
\hline Aegilops triuncialis (Barhed Goatgrass) & $\mathrm{x}$ & absent & occasional & numerous \\
\hline Baccharis pilularis (Coyote Brush) & & sparse & occasional & numerous \\
\hline Briza maxima (Big Quakinggrass) & $\mathrm{x}$ & absent & sparse & numerous \\
\hline Carduus pycnocephalus (Italian Thistle) & $\mathrm{x}$ & sparse & numerous & numerous \\
\hline Cerastium arvense (Field Chickweed) & $\mathrm{x}$ & absent & occasional & numerous \\
\hline Cynosurus echinatus (Hedgehog Dogtail) & $\mathrm{x}$ & occasional & occasional & numerous \\
\hline Dactylis glomerata (Orchardgrass) & $\mathbf{x}$ & sparse & occasional & numerous \\
\hline Holcus lanatus (Velvetgrass) & $\mathrm{x}$ & sparse & sparse & numerous \\
\hline Mentha pulegium (Pennyroyal) & $\mathrm{x}$ & absent & sparse & numerous \\
\hline Parentucellia viscosa & $\mathrm{x}$ & absent & absent & occasional \\
\hline Petrorhagia dubia & $\mathrm{x}$ & absent & rare & numerous \\
\hline Soliva sessilis & $\mathrm{x}$ & absent & absent & occasional \\
\hline Taeniatherum caput-medusae (Medusahead) & $\mathrm{x}$ & occasional & numerous & numerous \\
\hline Torilis arvensis (Japanese Hedge-parsley) & $\mathrm{x}$ & absent & absent & numerous \\
\hline
\end{tabular}

nal collection sites that would suggest species replacement. At the same time, rare plants are more susceptible to stochastic events, so it can't be ruled out entirely that some may have gone locally extinct. It is difficult to differentiate between what might have been a stochastic extinction and the inability to locate a species because of its rarity: Fischer and Stocklin (1997) noted a similar problem comparing old and new records of plant occurrence on calcareous grasslands in the Swiss Jura Mountains. They mentioned the possibility that species could have been missing in the new records without actually having gone extinct, if the old and new records were not taken at the same location. Similarly, many of our specimens had only vague location descriptions, such as "upper Orchard Pasture" or "Lake Biological Area", making it more difficult to locate the original collection site; more detailed location information was available for only 9 of the 43 missing plants.

Conversions of vegetation type appear to be responsible for the extirpation of at least 5 species. Pine grass (Calamagrostis rubescens Buckley) and serpentine Collomia (Collomia diversifolia E. Greene), the latter an uncommon California endemic, were last collected in the spring of 1957 . In the summer of the same year the woody vegetation of the 26 ha watershed where these plants occurred was removed and burned, and later seeded with a mixture of non-native clovers and grasses (Murphy 1976). Semaphore grass (Pleuropogon californicus (Nees) Vasey) and popcorn flower (Plagiobothrys stipitatus (E. Greene) I.M. Johnston var. micranthus (Piper) I.M. Johnston) were last collected in 1952 and 1953 along a seasonal watercourse; since then this pasture has been tilled and seeded numerous times with non-native grasses and clovers (unpublished pasture histories). Reed grass (Calamagrostis koelerioides Vasey) likely occurred on a chaparral site that has since been cleared and seeded with non-native grasses and forbs.

Thirteen of the 35 species that could not be relocated occurred originally on sites that have been under heavy grazing pressure. Heavy grazing can jeopardize the sustainability of grassland ecosystems by reducing soil fertility and water-holding capacity (Dormaar and Willms 1998), which can then lead to dominance of exotic annual species. At the same time, these sites have also undergone dramatic increases in several exotic species, notably big quaking grass, hedgehog dogtail, and barbed goatgrass in grasslands, and velvet grass (Holcus lanatus L.) and pennyroyal in wetland habitats (Table 4). The potential impact from either of these threats may play a role in the observed species loss. In particular, barbed goatgrass now dominates serpentine grassland sites and has become a threat to rangelands across California (Kennedy 1928, Peters et al. 1996). Previously, serpentine grasslands did not support extensive annual grass cover due to the low nutrient levels (Huenneke et al.1990) and had been regarded as refugia for California's native plants (Harrison 1999, Murphy and Ehrlich 1989). Therefore, documenting the spread of this invasive annual grass is of particular concern for native plant conservation.

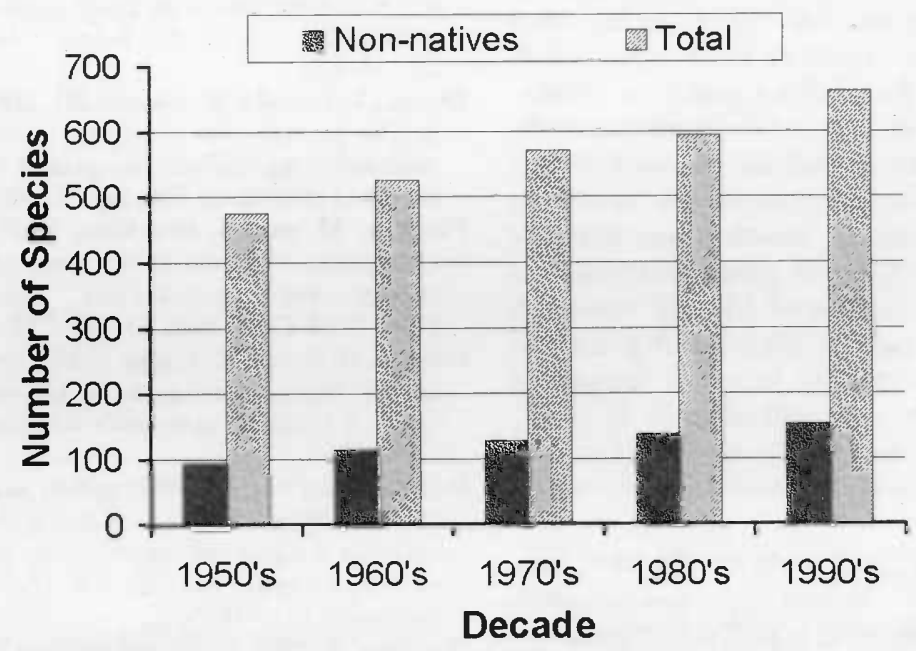

Fig. 1. Number of vascular plant species reported for the University of California Hopland Research and Extension Center, California. Over $2 / 3$ of the total number of species to date were collected between 1952 and 1954 following the establishment of the field station. 
The relatively recent establishment and spread of species such as big quaking grass, hedgehog dogtail, barbed goatgrass, velvet grass, and pennyroyal also has consequences for ecosystem function. Eviner and Chapin (2001) found differences in decomposition rates, net nitrogen cycling rates, and phosphorus availability between single species plots planted at the Center. In particular, barbed goatgrass plots had greatly enhanced net nitrification, and supported the highest gopher activity, suggesting that this species may provide a more stable soil surface preferred by gophers. This example illustrates how changes in the composition and relative abundance of herbaceous species can directly influence ecosystem function, resulting in alterations to the habitat that can further affect vertebrate densities. Another consequence of the spread of competitive annual grasses for hardwood rangeland conservation may be reduced oak regeneration, due primarily to competition for water (Gordon and Rice 1993). In addition to the consequences these exotics have for ecosystem function and biodiversity conservation, the quality of the livestock forage has been reduced. For example, pennyroyal, barbed goatgrass, hedgehog dogtail, and big quaking grass, have all undergone substantial increases in abundance at the Center, yet are highly unpalatable to livestock.

Early research at the Center focused on vegetation type conversions and reseeding with non-native species in order to enhance forage production and water yield, but this was not without costs. The conversion of a wooded 86 ha watershed resulted in a dramatic increase of 2 weedy species along with multiple soil slips and increases in sediment discharge (Pitt et al. 1978, Heady and Pitt 1979). On the other hand, fire has recently been used to dramatically reduce barbed goatgrass infestations in 2 pastures while simultaneously increasing the abundance of meadow barley (Hordeum brachyantherum Nevski), a native perennial bunchgrass; thereby improving forage for sheep (DiTomaso et al. 2001). The trend toward research directed at oak woodland and grassland ecosystems and the fact that rangeland conversion is no longer done for livestock production will undoubtedly slow the spread and establishment of invasive species.

Hardwood rangelands are the most biologically rich habitat type in California (Pavlik et al. 1991), making it essential that we monitor changes to their flora over time. Continued surveys at the Center will help verify local extinction and document new losses, as well as new additions to the flora. To better demonstrate the spread of invasive species, a monitoring program should be established that includes mapping the distribution of non-native species through time using the Center's existing Geographic Information System. While we note shifts in land-use as a likely cause for the observed changes to the flora, long-term experiments on the effects of livestock grazing and species introductions are essential to test the direct contribution that grazing and exotics have on native flora. In addition, a quantitative study comparing vegetation composition and abundance in similar plant communities on comparable soil types between grazed and ungrazed sites would be useful. Studies of this sort would complement this one and provide a better understanding of species turnover and the associated causes in north coast hardwood rangelands.

\section{Literature Cited}

Campbell, B.D. and D.M.S. Smith. 2000. A synthesis of recent global change research on pasture and rangeland production: Reduced uncertainties and their management implications. Agr. Ecosyst. Enviroment 82: 39-55.

D'Antonio, C.M. and P.M. Vitousek. 1992. Biological invasions by exotic grasses, the grass/fire cycle, and global change. Ann. Rev. Ecol. Syst. 23:63-87.

de Nevers, G. 1985. Pepperwood flora. Pepperwood Ranch Natural Preserve. Sonoma County, CA. California Academy of Sciences, San Francisco, Calif.

DiTomaso, J.M., K.L. Heise, G.B. Kyser, A.M. Merenlender, and R.J. Keiffer. 2001. Carefully timed burning can control barb goatgrass. Cal. Agr. 55(6):47-52.

Dormaar J.F. and W.D. Willms. 1998. Effect of forty-four years of grazing on fescue grassland soils. J. Range Manage. 51:122-126.

Eviner, V.T. and F.S. Chapin III. 2001. Plant species provide vital ecosystem functions for sustainable agriculture, rangeland management and restoration. Cal. Agr. 55(6):54-59.

Fischer, M. and J. Stocklin. 1997. Local extinctions of plants in remnants of extensively used calcareous grasslands 1950-1985. Cons. Biol. 11:727-737.

Gordon, D. R. and K. J. Rice 1993. Competitive effects of grassland annuals on soil water and blue oak (Quercus douglasii) seedlings. Ecol. 74: 68-82.

Hamilton, J.G., C. Holzapfel, and B.E. Mahall. 1999. Coexistence and interference between a native perennial grass and nonnative annual grasses in California. Oecologia 121:518-526.

Harrison, S. 1999. Local and regional diversity in a patchy landscape: Native, alien, and endemic herbs on serpentine. Ecol. 80:70-80.
Heady, H.F. 1977. Valley grassland. Pp. 491514 in M.G. Barbour and J. Major (eds.), Terrestrial vegetation of California. John Wiley and Sons, New York.

Heady, H.F. and M.D. Pitt. 1979. Reactions of northern California grass-Woodland to vegetational type conversions. Hilgardia 47:51-73.

Heise, K.L. and A.M. Merenlender. 1999. Flora of a vernal pool complex in the Mayacmas Mountains of southeastern Mendocino County, California. Madrono 46: 38-45.

Hickman, J. 1993. The jepson manual: Higher plants of California. University of California Press, Berkeley and Los Angeles, Calif.

Holzman B.A. and B.H. Allen-Diaz. 1991. Vegetation change in blue oak woodlands in California. USDA For. Serv. Gen. Tech. Rep. PSW-126.

Huenneke, L.F., S.P.Hamburg, R. Koide, H.A. Mooney, and P.M. Vitousek. 1990. Effects of soil resources on plant invasion and community structure in Californian [USA] serpentine grassland. Ecol. 71:478-491.

Jackson, L.E. 1985. Ecological origins of California's mediterranean grasses. J. Biogeog. 12:349-361.

Kennedy, P.B. 1928. Goatgrass or wild wheat (Aegilops triuncialis). J. Amer. Soc. Agron. 20:1292-1296.

Knops, J.M.H., J.R. Griffin, and A.C. Royalty. 1995. Introduced and native plants of the Hastings Reservation, central coastal California: A comparison. Biol. Cons. 71:115-123.

Mack, R. N. 1989. Temperate grasslands vulnerable to plant invasions: characteristics and consequences. Pp. 155-179 In J.A. Drake, H.A. Mooney, F. di Castri, R.H. Groves, F.J. Kruger, M. Rejmanek, and M. Williamson (eds.), Biological invasions: A global perspective. John Wiley \& Sons, Chichester, N.Y.

Major, J. 1955. Weeds on California rangelands. Cal. Agr. 9:3-4.

Mooney, H.A. and J.A. Drake. 1987. The ecology of biological invasions. Environ. 29:10-37.

Muick, P. C. and J. W. Bartolome. 1988. Factors associated with oak regeneration in California. Pp 86-91, In: T.R. Plumb and N. H. Pillsbury (Tech. Coord.). Proc. Symp. Multiple-use Management of California's Hardwood Resources. USFS Gen. Tech. Rep. PSW-100.

Murphy, A.H. 1976. Watershed management increases rangeland productivity. Cal. Agr. 30:16-21.

Murphy, A.H. 1978. Benefits of chaparral improvement to livestock and wildlife. Proc. Ann. Calif. Weed Conf. 30:84-91.

Murphy, A.H. and H.F. Heady. 1983. Vascular plants of the Hopland Field Station, Mendocino County, California. Wasmann J. Biol. 41:53-96.

Murphy, D.D. and P.R. Ehrlich. 1989. Conservation biology of California's remnant native grasslands. Pp 201-212. In: L.F. Huenneke and H.F. Mooney (eds.), Grassland structure and function: California annual grassland. Kluwer, Dordrecht. 
Pavlik, B.M., P.C. Muick, S.G. Johnson, and M. Popper. 1991. Oak of California, Cachuma Press and the California Oak Foundation. Los Olivos, Calif. 184 pp.

Peters, A., D.E. Johnson and M.R. George. 1996. Barb goatgrass: A threat to California rangelands. Rangelands 18(1): 8-10.

Pettit, N.E., R.H. Forend, and P.G. Ladd. 1995. Grazing in remnant woodland vegetation: Changes in species composition and life form groups. J. Veg. Sci. 6: 121-130.

Pitt, M.D., R.H. Burgy, and H.F. Heady. 1978. Influences of brush conversion and weather patterns on runoff from a northern California watershed. J. Range Manage. 31:23-27.
Randall, J.M., M. Rejmánek, and J.C. Hunter. 1998. Characteristics of the exotic flora of California. Fremontia 26:3-12.

Rejmanek, M., C.D. Thomsen, and I.D. Peters. 1991. Invasive vascular plants of California. Pp. 81-101. In: R.H. Groves, and F. di Castri (eds.). Biogeography of mediterranean invasions. Cambridge University Press, Cambridge.

Skinner M.W. and B.M. Pavlik. 1994. California Native Plant Society's Inventory of Rare and Endangered Vascular Plants of California. Special Publication No.1 (fifth edition). CNPS.
Vitousek, P.J. 1986. Biological invasions and ecosystem properties: Can species make a difference? Pp. 163-178 In: H.A. Mooney and J. Drake (eds.), Biological invasions of North America and Hawaii. Springer-Verlag, New York, N.Y. 